\title{
GONZALO VIDAL (1943-1997): UNA VIDA DEDICADA A LA INVESTIGACIÓN EN MICROPALEONTOLOGÍA DEL PRECÁMBRICO
}

\author{
Teodoro PALACIOS \\ Área Paleontología. Facultad de Ciencias. Universidad de Extremadura. E- \\ 06071 Badajoz.. España. Correo electrónico: medrano@guadiana.unex.es
}

El comienzo del año 1997 nos trajo una triste noticia, el profesor Gonzalo Vidal había fallecido el 10 de enero en Uppsala (Suecia) a causa de un infarto. Para los que le conocíamos y habíamos tenido el honor de compartir su trabajo, suponía una ausencia irreparable tanto en el sentido personal como en el científico; para la comunidad científica, la pérdida de uno de los mejores investigadores que ha dado la ciencia española en el campo de la Paleontología. Sus investigaciones estaban centradas en el estudio de microbiotas de edad Proterozoico-Cámbrico (1.700$500 \mathrm{Ma}$.) y su área de investigación abarcaba todo el mundo; como él mismo solía decir, la ciencia aborda problemas cuya solución no depende de las fronteras.

Su corta vida contrasta con su gran legado científico, 25 años de investigación en el Precámbrico y Cámbrico han supuesto un espectacular avance en los conocimientos paleobiológicos de esta época. Sus descubrimientos paleontológicos e interpretaciones ayudaron a dilucidar la Paleobiología de las microbiotas proterozoicas, y sus aportaciones han sido claves para comprender la evolución temprana de la vida y el desarrollo de los primeros ecosistemas. Aspectos tan críticos como la radiación explosiva del Cámbrico quedaron bastante clarificados con sus aportaciones, que apoyan un modelo darwiniano de la evolución durante este intervalo. Darwin achacaba a la falta de datos del registro fósil la aparente súbita aparición de vida en el Cámbrico. Como Gonzalo decía en uno de sus últimos artículos, «Vista desde esta perspectiva la explosión Cámbrica no es ni tan drástica ni tan misteriosa como las proposiciones iniciales la presentaron».

Gonzalo Vidal había nacido en Madrid el 29 de mayo de 1943, donde cursó sus estudios medios y comenzó estudios superiores de Ingeniería. Posteriormente se desplazó a Lund (Suecia), donde prosiguió su formación académica y obtuvo, en 1969, el Master of Science en el Departamento de Geología de la Universidad de Lund. En 1973 obtuvo el grado académico de Filosofie licentiate (equivalente al Doctorado) con la presentación de una Tesis en Micropaleontología del Precámbrico, obteniendo la máxima calificación. Postcriormente, en 1979, recibió el Filosofie doktorexamen en la Universidad de Lund por sus disertaciones sobre Micropaleontología y Bioestratigrafía del Precámbrico superior en Suecia y la región del Atlántico Norte.

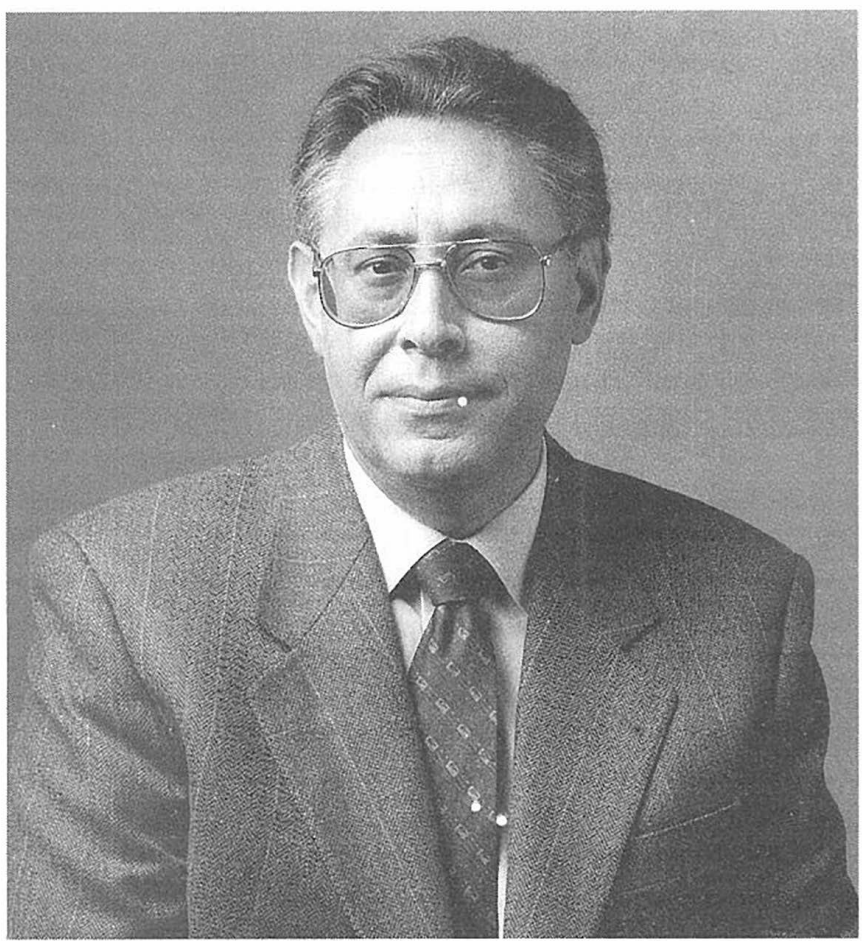

Cuando comenzó su tesis doctoral, uno de los mayores retos en Paleontología era la búsqueda de microfósiles en el Precámbrico. Dichas investigaciones estaban todavía en su infancia, con apenas 20 publicaciones sobre el tema que se agrupaban en dos tendencias. La escuela rusa, cuyos máximos representantes eran B. V. Timofeev, S. N. Naumova y N. A. Volkova, y que centraba sus estudios de tipo bioestratigráfico en microfósiles planctónicos extraídos mediante técnicas palinológicas. Por otra parte estaba la escuela norteamericana, representada por E. S. Barghoorn, S. A. Tyler y J. W. Schopf, cuyos estudios fundamentalmente paleobiológicos se centraban en el estudio mediante secciones delgadas de las microbiotas contenidas en rocas silíceas (cherts) de formaciones estromatolíticas. En este marco Gonzalo inició sus investigaciones.

La experiencia adquirida por Gonzalo Vidal en sus trabajos previos de investigación minera y cartografía geológica, unida a su especialización en Palinología y en Sistemática llevando a cabo varios proyectos en polen y esporas mesozoicos y actuales, le proporcionó una amplia formación en Geología y Biología, que sería determinante en sus posteriores investigaciones. 
Sus estudios sobre microfósiles, con un enfoque multidisciplinar que conjugaba aspectos paleobiológicos y bioestratigráficos, supusieron el punto de partida para la fusión de las escuelas rusa y norteamericana y el inicio de una nueva forma de estudio globalizadora de los ecosistemas del Precámbrico.

Sus interpretaciones eran originales y alejadas de todo aquello que supusiera dogmatismo en ciencia. Por ello a veces crearon fuerte polémica, aunque en la mayoría de los casos el tiempo le dio la razón y hoy son punto de referencia en las investigaciones del Proterozoico.

Gonzalo fue un modesto investigador que nunca persiguió entrar en las altas instancias académicas ni buscó reconocimiento, aunque tuvo la gran satisfacción de ver cómo sus ideas eran aceptadas. Técnicamente fue un gran innovador, diseñando y construyendo sus propios aparatos para extraer microfosiles. Combinó su investigación con actividades académicas, impartiendo cursos de doctorado y dirigiendo varias tesis doctorales.

En 1980 obtuvo la plaza de Profesor Asociado de Geología Histórica y Paleontología en la Universidad de Lund, y en 1988 la de Profesor de Micropaleontología del Consejo Sueco de Investigación en Ciencias Naturales, dirigiendo un Laboratorio de Micropaleontología en la Universidad de Lund, que posteriormente trasladó en 1991 a la Universidad de Uppsala donde se estableció como Profesor a partir de 1994.

Gonzalo adquirió su visión del mundo natural pretérito combinando sus meticulosos estudios microscópicos en el laboratorio con sus observaciones en el campo, fruto de sus campañas y expediciones en Australia, Nueva Zelanda, la Antártida, América del Norte, Canadá, Escandinavia, Urales, Siberia, China y en casi todos los países europeos, fundamentalmente España. Entre otras, organizó y dirigió expediciones en el Ártico (Noruega, Groenlandia, Siberia y Penínsulas de Kanin y Kola). También participó activamente en varios proyectos internacionales sobre Bioestratigrafía, Quimioestratigrafia, correlaciones geológicas y Paleoecología.

Su actividad investigadora le llevó a distintos centros de investigación del mundo, disfrutando de puestos como Post-doctoral Research Fellow en Nueva Zelanda, Research Fellow y profesor visitante de la Universidad de California en Los Angeles (UCLA), Research Fellow de intercambio entre la Real Academia Sueca de Ciencias y la antigua Unión Soviética, China y Polonia, y beca Fulbright y profesor visitante en la Universidad de Harvard. Una de sus últimas actividades de relevancia fue la propuesta y co-organización en 1992 del Nobel Symposium "Early Life on Earth" en Uppsala.

Su actividad investigadora en España comenzó en el año 1983 con la co-dirección de la tesis doctoral que el firmante estaba realizando sobre microfósiles del Precámbrico del centro de España. Sus enseñanzas y fuerte espíritu crítico fueron decisorias para mi formación y el inicio de una serie de investigaciones críticas frente a la concepción tradicional del
Proterozoico y Cámbrico basal de España. La culminación de esta colaboración fue su incorporación en 1992 al Área de Paleontología de la Universidad de Extremadura durante tres meses al año, como "Catedrático Programa Propio" del Ministerio de Educación y Ciencia. El fruto de estos años de colaboración ha permitido dilucidar diversos aspectos paleontológicos y geológicos de la compleja problemática del Neoproterozoico y Cámbrico de la Península Ibérica mediante estudios multidisciplinares (Paleontología, Bioestratigrafía, Quimioestratigrafía, Geodinámica y Paleogeografía). Éstos se han concretado en el Proyecto de Investigación de la DGICYT PB93-0410 "Contexto paleobiológico, geodinámico y paleogeográfico del NeoproterozoicoCámbrico inferior en Iberia", produciéndose su muerte antes de la conclusión del mismo.

Las dos últimas campañas de campo que hicimos juntos fueron enormemente fructíferas y pudimos compartir con entusiasmo el descubrimiento de espectaculares yacimientos de small shelly fossils que coexistían con los trilobites más antiguos de la Península Ibérica. El recuerdo de este feliz momento es el que quiero evocar ahora para compensar esta irreparable pérdida del que fue un gran amigo y mejor Profesor. Como me decía otro gran amigo suyo, el Profesor Ricardo Guerrero, al notificarme su fallecimiento: "Sé que tanto tú como yo, además de a un gran científico, hemos perdido a un amigo cabal".

\section{PUBLICACIONES (EN ORDEN CRONOLÓGICO)}

Vidal, G. and Röshoff, K. 1971. Organic remains in metasedimentary and metatuffitic rocks of the Vetlanda Series, South Sweden. A preliminary Report. Geologiska Föreningens $i$ Stockholm Förhandlingar, 93, 773-778.

Vidal, G. 1972. Algal stromatolites from the Late Precambrian of Sweden. Lethaia, 5, 353-368.

Vidal, G. 1974. Late Precambrian microfossils from the basal sandstone unit of the Visingsö beds, South Sweden. Geologica et Palaeontologica, 8, 1-14.

Vidal, G. 1976. Late Precambrian microfossils from the Visingsö Beds in southern Sweden. Fossils and Strata, 9 , $1-57$.

Vidal, G. 1976. Late Precambrian acritarchs from the Eleonore Bay Group and Tillite Group in East Greenland. A preliminary report. Rapport Gronlands geologiske Undersøgelse, 78, 1-19.

Vidal, G. 1977. Late Precambrian microfossils. Gelogical Magazine, 114, 393-394.

Vidal, G. 1979. Acritarchs and the correlation of the Upper Proterozoic. Publications Institute Mineralogy, Paleontology and Quaternary Geology, University of Lund, 219, 1-22.

Vidal, G. 1979. Acritarchs from the Upper Proterozoic and Lower Cambrian of East Greenland. Gronlands geologiske Undersøgelse Bulletin, 134, 1-40.

Vidal, G. and Dawes, P. R. 1980. Acritarchs from the 
Proterozoic Thule Group, North-West Greenland. Rapport Grønlands geologiske Undersøgelse, 100, 24-29.

Knoll, A. H. and Vidal, G. 1980. Late Proterozoic vaseshaped microfossils from the Visingsö Beds, Sweden. Geologiska Föreningens i Stockholm Förhandlingar, 102, 207-211.

Vidal, G. 1981. Micropalaeontology and biostratigraphy of the Upper Proterozoic and Lower Cambrian sequences in East Finnmark, Northern Norway. Norges geologiske Unders $\phi$ kelse, 362, 1-53.

Vidal, G. 1981. Lower Cambrian acritarch stratigraphy in Scandinavia. Geologiska Föreningens i Stockholm Förhandlingar, 103, 183-192.

Vidal, G. 1981. Aspects of problematic acid-resistant, organic-walled microfossils (acritarchs) in the Upper Proterozoic of the north Atlantic region. Precambrian Research, 15, 9-23.

Vidal, G. 1981. Micropalaeontology and biostratigraphy of the Lower Cambrian sequence in Scandinavia. In: Short Papers for the Second International Symposium on the Cambrian System. (Ed. M. E. Taylor). United States Geological Survey, Open File Report, 81-743, 232-235.

Vidal, G. and Bylund, G. 1981. Late Precambrian boulder beds in the Visingsö beds, south Sweden. In: Earth's PrePleistocene Glacial Record. (Eds. M. J. Hambrey and W. B. Harland). Cambridge University Press, Cambridge, 629-631.

Pożaryski, W., Vidal, G. and Brochwicz-Lewiński, W. 1981. New data on the Lower Cambrian at the southern margin of the Holy Cross Mts. (SE Poland). Bulletin de l'Académie Polonaise des Sciences, Série des Sciences de la Terre, 29,167-174.

Pożaryski, W., Vidal, G. i Brochwicz-Lewiński, W. 1981. Nowe dane o dolnym kambrze południowego obrzeżenia Gór Świętokrzyskich. In: Przewodnik 53 Zjazdu Polskiego Towarzystwa Geologicznego, Kielce. Instytut Geologiczny, Warszawa, 27-34.

Vidal, G. 1982. Den prepaleozoiska sedimentära berggrunden. In: Beskrivning till berggrundskartan $\mathrm{Hjo}$ NO. (Eds. H. Wikman, A. Bruun, B. Dahlman och G. Vidal). Sveriges Geologiska Undersökning, Serie Af., 120, 52-76.

Vidal, G. and Knoll, A. H. 1982. Radiations and extinctions of plankton in the late Proterozoic and early Cambrian. Nature, 297, 57-60.

Brown, A. V., Cooper, R. A., Corbett, K. D., Daily, B., Green, G. R., Grindley, G. W., Jago, J. B., Laird, M. G., Vandenberg, A. H. M, Vidal, G., Webby, B. D. and Wilkinson, H. E. 1982. Late Proterozoic to Devonian sequences of southeastern Australia, Antarctica and New Zealand and their correlation. Geological Society of Australia Special Publication, 9, 1-193.

Cooper, R. A., Jago, J. B., MacKinnon, D. I., Shergold, J. H., \& Vidal, G. 1982. Late Precambrian and Cambrian fossils from Northern Victoria Land and their stratigraphic implications. In: Antarctic GeosciencesSymposium on Antarctic Geology and Geophysics, Madison, Wisconsin, USA, August 22-27, 1977. (Ed. C. Craddock). The University of Wisconsin Press, Madison, 629-633.
Vidal, G. 1983. Microorganismos planctónicos fósiles. Investigación y Ciencia, 83, 8-19. [Edición española de Scientific American.]

Vidal, G. and Knoll, A. H. 1 983. Proterozoic plankton. Geological Society of America Memoir, 161, 265-277.

Vidal, G. and Siedlecka, A. 1983. Planktonic, acid-resistant microfossils from the Upper Proterozoic strata of the Barents Sea region of Varanger Peninsula, East Finnmark, Northern Norway. Norges geologiske Unders $\phi$ kelse, 382, 45-79.

Mansuy, C. and Vidal, G. 1983. Late Proterozoic Brioverian microfossils from France: taxonomic affinity and implications of plankton productivity. Nature, 302, 606607.

Vidal, G. 1984. The oldest eukaryotic cells. Scientific American, 250, 48-57.

Vidal, G. 1985. Biostratigraphic correlation of the Upper Proterozoic and Lower Cambrian of the Fennoscandian Shield and the Caledonides of East Greenland and Svalbard. In: The Caledonide Orogen-Scandinavia and Related Areas. (Eds. D. G. Gee and B. A. Sturt). John Wiley \& Sons Ltd, Chichester, 331-338.

Vidal, G. 1985. Prepaleozoisk sedimentberggrund. In: Beskrivning Till Berggrundskartan Hjo SO. (Eds. L. Persson, A. Bruun och G. Vidal). Sveriges Geologiska Undersökning, Serie Af., 134, 77-91.

Vidal, G. and Ford, T. D. 1985. Microbiotas from the late Proterozoic Chuar Group (northern Arizona) and Uinta Mountain Group (Utah) and their chronostratigraphic implications. Precambrian Research, 28, 349-389.

Dawes, P. and Vidal, G. 1985. Proterozoic age of the Thule Group: new evidence from microfossils. Rapport Grønlands geologiske Undersøgelse, 125, 22-28.

Brochwicz-Lewiński, W., Vidal, G., Pożaryski, W., Tomczyk, H. et Zając, H. 1986. Position tectonique du massif de Haute-Silésie avant le Permien à la lumière de données nouvelles sur le Cambrien de cette région. Comptes Rendus de l'Académie des Sciences, Série 11, 303 (16), 1493-1496.

Germs, G. J. B, Knoll, A. H. and Vidal, G. 1986. Latest Proterozoic microfossils from the Nama Group, Namibia (South West Africa). Precambrian Research, 32, 45-62.

Moczydlowska, M. and Vidal, G. 1986. Lower Cambrian acritarch zonation in southern Scandinavia and southeastern Poland. Geologiska Föreningens $i$ Stockholm Förhandlingar, 108, 201-223.

Vidal, G. 1987. Subdivision of Precambrian time: recommendations and suggestions by the Subcommission on Precambrian Stratigraphy. Precambrian Research, 36, 177-178.

Vidal, G. and MoczydXowska, M. 1987. Further reflections on metazoan evolution. Precambrian Research, 36, 345348.

Vidal, G. 1988. A palynological preparation method. Palynology, 12, 215-220.

Vidal, G. 1988. Urtida algblomning satte fart på livet. Forskning och Framsteg, 7, 35-40.

Vidal, G. and Peel, J. S. 1988. Acritarchs from the Buen Formation (Lower Cambrian), North Greenland. Rapport Gronlands geologiske Unders $\phi$ gelse, 137, 1-54. 
Moczydlowska, M. and Vidal, G. 1988. How old is the Tommotian? Geology, 16, 166-168.

MoczydYowska, M. and Vidal, G. 1988. Early Cambrian acritarchs from Scandinavia and Poland. Palynology, 12, $1-10$.

Peel, J. S. and Vidal, G. 1988. Acritarchs from the Kap Holbæk Formation, North Greenland. Rapport Gronlands geologiske Undersøgelse, 137, 42.

Vidal, G. 1989. Are late Proterozoic carbonaceous megafossils metaphytic algae or bacteria? Lethaia, 22, 375-379.

Morad, S. and Vidal, G. 1989. Proterozoic Mn-oxide precipitation by planktonic plant protists (acritarchs). Geological Magazine, 126, 301-305.

Vidal, G. 1990. Giant acanthomorph acritarchs from the Upper Proterozoic in southern Norway. Palaeontology, 33, 287-298.

Vidal, G. 1990. The late Proterozoic acritarch Chuaria circularis (Walcott) Vidal and Ford. Journal of Paleontology, 64, 488.

Vidal, G. and Nystuen, J. P. 1 990. Micropalaeontology, depositional environment, and biostratigraphy of the Upper Proterozoic Hedmark Group, southern Norway. American Journal of Science, 290-A, 170-211.

Vidal, G. and Nystuen, J. P. 1990. Lower Cambrian acritarchs and the Proterozoic cambrian boundary in southern Norway. Norsk Geologisk Tidsskrift, 70, 191222.

Vidal, G. and Moczydlowska, M. 1992. Patterns of radiation in the phytoplankton across the Precambrian-Cambrian boundary. Journal of the Geological Society, 149, 647654.

Farmer, J., Vidal, G., MoczydYowska, M., Strauss, H., Ahlberg, P. and Siedlecka, A. 1992. Ediacaran fossils from the Innerelv Member (late Proterozoic) of the Tanafjorden area, northeastern Finnmark. Geological Magazine, 129, 181-195.

Moczydlowska, M. and Vidal, G. 1 992. Phytoplankton from the Lower Cambrian Læså formation on Bornholm, Denmark: biostratigraphy and palaeoenvironmental constraints. Geological Magazine, 129, 17-40.

Palacios, T. and Vidal, G. 1992. Lower Cambrian acritarchs from northern Spain: the Precambrian-Cambrian boundary and stratigraphic implications. Geological Magazine, 129, 421-436.

Strauss, H., Bengtson, S., Myrow, P. and Vidal, G. 1992. Stable isotope geochemistry and palynology of the late Precambrian to Early Cambrian sequence in Newfoundland. Canadian Journal of Earth Sciences, 29, 1662-1673.

Vidal, G. 1993. Bio/chemo events-helping to elucidate the depositional and tectonic history of disrupted basins. Publications of the Institute of Geophysics, Polish Academy of Sciences, A-20, 153-155.

Vidal, G., Moczydlowska, M. and Rudavskaya, V. A. 1993. Biostratigraphical implications of a Chuaria-Tawuia assemblage and associated acritarchs from the Neoproterozoic of Yakutia. Palaeontology, 36, 387-402.

Vidal, G. and Peel, J. S. 1993. Acritarchs from the Lower Cambrian Buen Formation in North Greenland.
Grønlands geologiske Undersøgelse Bulletin, 164, 1-35.

Moczyd \owska, M. and Vidal, G. 1993. Lower and Middle Cambrian acritarch-based biozonation of the Baltic Syneclise and adjacent areas (East European Platform)-a few remarks. Przeglad Geologiczny, 2, 109-110.

Moczydlowska, M., Vidal, G. and Rudavskaya, V. A. 1993. Neoproterozoic (Vendian) phytoplankton from the Siberian Platform, Yakutia. Palaeontology, 36, 495-521.

Vidal, G. 1994. Early ecosystems: Limitations imposed by the fossil record. In: Early Life on Earth. Nobel Symposium No. 84. (Ed. S. Bengtson). Columbia University Press, New York, 298-311.

Vidal, G., Jensen, S. and Palacios, T. 1994. Neoproterozoic (Vendian) ichnofossils from Lower Alcuthan strata in central Spain. Geological Magazine, 131, 169-179.

Vidal, G., Palacios, T., Gámez-Vintaned, J. A., Díez Balda, M. A. and Grant, S. 1994. Neoproterozoicearly Cambrian geology and palaeontology of Iberia. Geological Magazine, 131, 729-765.

Vidal, G. 1995. Life in the Proterozoic. Lethaia Reviews. Lethaia, 28, 84.

Vidal, G. 1995. La explosión Cámbrica: antecedentes de la vida animal. In: Ciencia, Tecnología, Medio Ambiente. Anuario 1996. Ediciones El País, Madrid, 106-111.

Vidal, G. and Moczydlowska, M. 1995. The Neoproterozoic of Baltica-stratigraphy, palaeobiology and general geological evolution. Precambrian Research, 73, 197216.

Vidal, G. and MoczydYowska, M. 1995. Changes in Neoproterozoic-Cambrian phytoplankton biodiversity. In: XIII Reunión de Geología del Oeste Peninsular, Caracterización y evolución de la cuenca Neoproterozoica-Cámbrica en la Península Ibérica. Annual IGCP Project-319 Meeting: Global Paleogeography in the Upper Precambrian-Lower Cambrian. Regional IGCP Project-320 Meeting: Neoproterozoic Events and Resources. Comunicaciones. Salamanca-Coimbra, 19-30 de Septiembre de 1995. (Eds. M. D. Rodríguez Alonso and J. C. Gonzalo Corral). Signo, S. L., Salamanca, 3031.

Vidal, G., Moczydlowska, M. and Rudavskaya, V. A. 1995. Constraints on the early Cambrian radiation and correlation of the Tommotian and Nemakit-Daldynian regional stages of eastern Siberia. Journal of the Geological Society, 152, 499-510.

Vidal, G., Palacios, T., Moczydlowska, M. and Lorenzo Alvarez, S. 1995. A new find of "Tommotian" small shelly fossils from southern Spain. In: XIII Reunión de Geología del Oeste Peninsular, Caracterización y evolución de la cuenca Neoproterozoica-Cámbrica en la Península Ibérica. Annual IGCP Project-319 Meeting: Global Paleogeography in the Upper PrecambrianLower Cambrian. Regional IGCP Project-320 Meeting: Neoproterozoic Events and Resources. Comunicaciones. Salamanca-Coimbra, 19-30 de Septiembre de 1995. (Eds. M. D. Rodríguez Alonso and J. C. Gonzalo Corral). Signo, S. L., Salamanca, 166-167.

Compston, W., Sambridge, M. S., Reinfrank, R. F., Moczydlowska, M., Vidal, G. and Claesson, S. 1995. Numerical ages of volcanic rocks and the earliest faunal 
zone within the Late Precambrian of east Poland. Journal of the Geological Society, 152, 599-611.

Eguiluz, L., Palacios, T., Vidal, G., Moczydlowska, M. and Apraiz, A. 1995. Day 1: September 20 th. Transverse Valley of Matamoros-Embalse de Guadajira (Upper Neoproterozoic-Lower Cambrian). In: XIII Gcological Meeting on the West of the Iberian Peninsula, Characterization and evolution of the NeoproterozoicCambrian Basin on the Iberian Peninsula. Annual IGCP Project-319 Meeting: Global Paleogeography in the Upper Precambrian-Lower Cambrian. Regional IGCP Project -320 Meeting: Neoproterozoic Events and Resources. Pre-Conference Field Guide. Neoproterozoic-Cambrian Transect of Sierra Morena and Montes de Toledo. Spain. September, 19-24th. 1995. Signo, S.L., Salamanca, 3-8.

Palacios, T., Eguiluz, L., Vidal, G. and Moczydlowska, M. 1995. Day 3: September 22 th. Castañar de Ibor-Hospital del Obispo (Ibor Anticline). In: XIII Geological Meeting on the West of the Iberian Peninsula, Characterization and evolution of the Neoproterozoic-Cambrian Basin on the Iberian Peninsula. Annual IGCP Project-319 Meeting: Global Paleogeography in the Upper Precambrian-Lower Cambrian. Regional IGCP Project320 Meeting: Neoproterozoic Events and Resources. Pre-Conference Field Guide. Neoproterozoic-Cambrian Transect of Sierra Morena and Montes de Toledo. Spain. September, 19-24th. 1995. (Eds. M. D. Rodríguez Alonso and G. Alonso Gavilán). Signo, S.L., Salamanca, 32-37.

Palacios, T., Eguiluz, L., Vidal, G., MoczydYowska, M., Alonso Gavilán, G. and Rodríguez Alonso, M. D. 1995. Day 5: September 24th. Cíjara Formation (Domo Extremeño group) and Membrillar olistostrome. In: XIII Geological Meeting on the West of the Iberian Peninsula, Characterization and evolution of the Neoproterozoic-Cambrian Basin on the Iberian Peninsula. Annual IGCP Project-319 Meeting: Global Paleogeography in the Upper Precambrian-Lower Cambrian. Regional IGCP Project-320 Meeting: Neoproterozoic Events and Resources. Pre-Conference Field Guide. Neoproterozoic-Cambrian Transect of Sierra Morena and Montes de Toledo. Spain. September, 19-24th. 1995. Signo, S.L., Salamanca, 45-49.

Palacios, T., Moczydlowska, M. and Vidal, G. 1995. A first record of Platysolenites antiquissimus Eichwald (Lower Cambrian) in Iberia. In: XIII Reunión de Geología del Oeste Peninsular, Caracterización y evolución de la cuenca Neoproterozoica-Cámbrica en la Península Ibérica. Annual IGCP Project-319 Meeting: Global Paleogeography in the Upper Precambrian-Lower Cambrian. Regional IGCP Project-320 Meeting: Neoproterozoic Events and Resources. Comunicaciones. Salamanca-Coimbra, 19-30 de Septiembre de 1995. (Eds. M. D. Rodríguez Alonso and J. C. Gonzalo Corral). Signo, S. L., Salamanca, 122-123.

Palacios, T. and Vidal, G. 1 995. The lbor and Valdelacasa anticlines. In: XIII Geological Meeting on the West of the
Iberian Peninsula, Characterization and evolution of the Neoproterozoic-Cambrian Basin on the Iberian Peninsula. Annual IGCP Project-319 Meeting: Global Paleogeography in the Upper Precambrian-Lower Cambrian. Regional IGCP Project-320 Meeting: Neoproterozoic Events and Resources. Pre-Conference Field Guide. Neoproterozoic-Cambrian Transect of Sierra Morena and Montes de Toledo. Spain. September, 19-24th. 1995. (Eds. M. D. Rodríguez Alonso and G. Alonso Gavilán). Signo, S. L., Salamanca, 22-31.

Strauss, H., Grant, S. W. F., Palacios, T. and Vidal, G. 1995. Carbon and sulfur isotopes in Neoproterozoic and Early Paleozoic sedimentary rocks from Central and Northern Spain. In: XIII Reunión de Geología del Oeste Peninsular, Caracterización y evolución de la cuenca Neoproterozoica-Cámbrica en la Península Ibérica. Annual IGCP Project-319 Meeting: Global Paleogeography in the Upper Precambrian-Lower Cambrian. Regional IGCP Project-320 Meeting: Neoproterozoic Events and Resources. Comunicaciones. Salamanca-Coimbra, 19-30 de Septiembre de 1995. (Eds. M. D. Rodríguez Alonso and J. C. Gonzalo Corral). Signo, S. L., Salamanca, 163-164.

Vidal Molinero, G. 1996. Bioeventos del Proterozoico y Cámbrico. In: Comunicaciones de las XII Jornadas de Paleontología: Badajoz, 30 de octubre-2 de noviembre de 1996. (Eds. T. Palacios y R. Gozalo). Universidad de Extremadura, Servicio de Publicaciones, Cáceres, 3-8.

Vidal, G. and Moczydlowska, M. 1996. Vendian-Lower Cambrian acritarch biostratigraphy of the central Caledonian fold belt in Scandinavia and the palaeogeography of the lapetus-Tornquist seaways. Norsk Geologisk Tidsskrift, 76, 147-168.

Palacios, T. y Vidal, G. 1996. Excursión. B. 1. El Neoproterozoico Superior-Cámbrico Inferior del centro de España. In: Comunicaciones de las XII Jornadas de Paleontología: Badajoz, 30 de octubre-2 de noviembre de 1996. (Eds. T. Palacios y R. Gozalo). Universidad de Extremadura, Servicio de Publicaciones, Cáceres, 170179.

Palacios, T., Vidal, G. and MoczydYowska, M. 1996. Palaeontological record of the Neoproterozoic-Lower Cambrian in Iberia- biochronological and palaeobiogeographical implications. In: II Field Conference of the Cambrian Stage Subdivision Working Groups. International Subcommission on Cambrian Stratigraphy. Spain, 13-21 September 1996. Field trip guide and abstracts. (Eds. E. Liñán, J. A. Gámez Vintaned and R. Gozalo). Universidad de Zaragoza, Zaragoza, 110-113.

Vidal, G. and MoczydYowska, M. 1997. Biodiversity, speciation and extinction trends of Proterozoic and Cambrian phytoplankton. Paleobiology, 23, 230-246.

Strauss, H., Vidal, G., Moczydlowska, M. and Pacześna, J. 1997. Carbon isotope geochemistry and palaeontology of Neoproterozoic to early Cambrian siliciclastic successions in the East European Platform, Poland. Geological Magazine, 134, 1-16. 